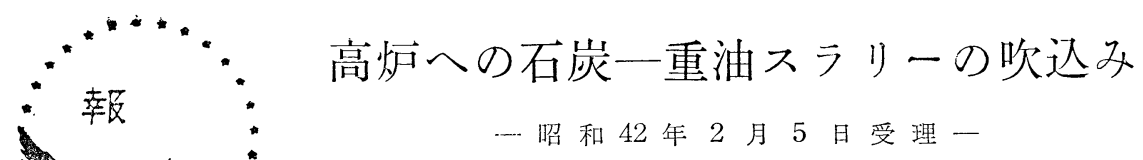

富士製鉄株式会社 森永 孝三・田島喜久雄 城本 義光・金山 有治 松岡宏

\section{I . 緒言}

国内に良翼の粘繥炭を産出しないわが国においては そのほとんどを海外に依存しているため, 鉎鉄の製造 に掠いてコークス比の低下をはかることが，夺つとも 重要な研究課題であつた。それ的えコークス製造技術 の向上，装入原料の整粒など数多くの努加がなされ， その結果わが国のコークス比は常に世界最低というす ばらしい成績を維持しているが，なお一層の低下が望 まれている。

最近, 高炉羽口より補助燃料吹込みの技術が開発さ れたが，この技術弾にコークス比の低下だけにとど まらず，銑鉄の增扊に刘してもきわめて效果的である ので, その普及注めざましく, 現在わが国のほとんど の高炉に採用されている。しかしながら, 燃料は一, 二の高炉を除きすべてが重油である。

重油注, 分解熱が大きく熱補償の点から吹込み量に 制約をうけ，また，銑鉄中のイオウ含有量を高めると いら久点がある。したがつて，吹込み量をさらにま し, よりコストの低減と品質の向上をはかるために は，熱補償が少なくてすむ水素含有量の少ない，乙か もイオウ含有量も少ない石炭などの燃料を使用すべき である。

さいわい，当室蘭製鉄所が立地している北海道に産 する石炭は, イオウ含有量が少なく,また近年の選炭 技術の向上によつて, 従来廃棄されていた尾鉱からま だ用途が十分開拓されていない安価な微粉炭がかなり の量回収されるようになつたので, このような石炭を 補助燃料とすることにより, 上記の問題点は解決され るであろら。

しかしながら，わが国の石炭の価格はかなり変動す るので, 石炭専用の設備により石炭単味吹込みを行な うよりも, 石炭と重油を混合したスラリ一状の燃料を 吹込さ技術を確立し，石炭価格の変動に応じて石炭の 混合割合をかえた燃料を吹込み，場合によつては同一 設備で重油単味吹込みにも切替えうる方法のほうが，
常にコスト低減をはかる上で有利である。

そこでわれわれは，1961年度から石炭一重油スラリ 一を高炉に吹込をための研究に着手し，1963年初め， 当室蘭製鉄所の内容積 $1,042 \mathrm{~m}^{3}$ の第 1 高炉に実際操 業に対処しうる試験設储を設置し, 工業化試験を重さ 祀た。その後, 同高炉の改修 (内容積 $1,126 \mathrm{~m}^{3}$ ) をま つて，1967年1月より，新設備による実際操業に入 り, 出鍇口の両側を除く羽口16本からスラリ一吹込み を行なつている。

\section{II. 基礎研究}

高炉への石炭一重油スラリ一吹込みの技術を確立す るための基礎として, 石炭の選定およびスラリーの性 状を的確に知ることにつとめた。

1）吹込为用石炭

石炭一重油スラリーにした場合, どの程度石炭自体 の燃燒特性がスラリーとしてのそれに寄与するかは明 らかでないが, 高炉羽口からの熱風の吹込み速度が $180 \mathrm{~m} / \mathrm{s}$ 以上にもなる高速であること, 羽口先の燃焼 帯が非常に小さいことなどを考えると, やはり石炭自 体の燃燒性がかなり関与するとみるべきである。

そこでわれわれは, 実験室的に単味噴射の燃焼性試 験装置を製作し, 燃燒性比較試験を行なつた。

結果は Table 1 に示すようで, これからも明らか のように揮発分の多い北海道炭がもつともすぐれてい ることがわかつた。さらに，北海道炭のなかでも非粘 結のものは, 粘結性を有するものとは異なつて, 噴射 バーナーの先端に漸次粘着してあなを閉塞するような 㲘念がないので, スラリ一用炭としては, 非粘結の北 海道一般炭を使用する方が好ましいと判断された。

2) 石炭の粒度

重油を担体として石炭をスラリ一状で輸送し, 炉内 に吹込む場合，石炭の粒度に関してつぎの諸条件を満 している必要がある。

（1）輸送時の管内抵抗を最小にするような構成で あること。 
Table 1 Results of coal combustion test

Coal analysis

$\begin{array}{cccccccc}\mathrm{H}_{2} \mathrm{O} & \text { Ash } & \text { V.M. } & \begin{array}{c}\text { Heat } \\ \text { value } \\ \mathrm{kcal} / \mathrm{kg}\end{array} & \mathrm{C} & \mathrm{H} & \mathrm{O} & \mathrm{S} \\ \% & \% & \% & \% & \%\end{array}$

Combustion results

Unburned Mean temp. Temp. coal ratio in furnace in stack $\mathrm{kg} / \mathrm{kg}$-coal $\quad{ }^{\circ} \mathrm{C} \quad{ }^{\circ} \mathrm{C}$

Hokkaidōo

\begin{tabular}{|c|c|c|c|c|c|c|c|c|c|c|}
\hline A & 11.9 & 10.4 & 45.3 & 6,590 & 68.0 & 5.6 & 9.8 & 0.21 & 0.078 & 735 \\
\hline B & 7.2 & 8.7 & 43.8 & 6,405 & 68.8 & 6.1 & 15.0 & 0.45 & 0.139 & 703 \\
\hline C & 3.1 & 11.2 & 42.2 & 6,843 & 70.2 & 5.9 & 11.0 & 0.28 & 0.248 & 623 \\
\hline $\mathrm{D}$ & 2.2 & 10.9 & 38.9 & 7,052 & 71.8 & 5.6 & 10.1 & 0.33 & 0.318 & 618 \\
\hline Coalite & 7.2 & 15.2 & 16.4 & 5,777 & 66.5 & 3.4 & 13.5 & 0.20 & 0.312 & 525 \\
\hline Medvezhk & 1.2 & 9.6 & 14.9 & 5,390 & 80.1 & 3.9 & 5.6 & 0.39 & 0.550 & 208 \\
\hline Souchang & 2.0 & 14.2 & 10.6 & 7,110 & 75.6 & 3.3 & - & 0.80 & No burn & \\
\hline Peru & 1.0 & 12.8 & 4.2 & 6,930 & - & - & - & 0.90 & No burn & \\
\hline
\end{tabular}

（2）沈降に対する安定性の面加ら微粉部分（50\% 以下）功適当量含まれていること1)。

（3）噴射バーナ一のあなを閉塞しない粒度範团の ものであること。

しかしながら，これを理論的に求めることはきわめ て困難であるので，水平部 $15 \mathrm{~m}$ のスラリー輸送実験 装置により検討を行なつた。

その結果, Fig.1 に示すような粒度構成のものが， 総合的にもつともよいことがわかつた。

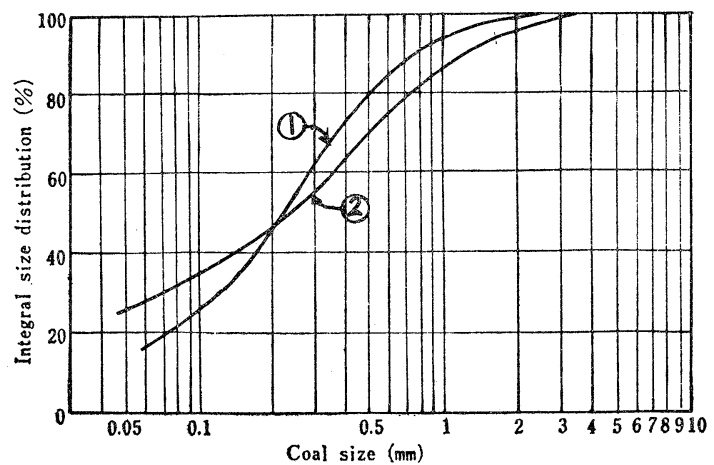

(1) Fuji Iron and Steel Co. (Muroran Works)

(2) Consolidation Coal Co.

Fig. 1 Coal Size distribution in slurry

参考までに，Fig. 1 にはコンソル社の石炭-水系に 対するデーターを記載した ${ }^{1)}$ 。この粒度構成は，同社 がスラリ一輸送においてもつとも適しているものとし て特許をとつたデーターである。

両者を比較するとかなり異なつているが，これは輸 送目的，輸送量，担体である液体のちがいなどによる
ものと考えられ，特に重油を担体とした場合にはその 粘度分高いため，懸濁して沈降を防せぐ第 2 母液をつ くる微粉部分が少なくてもよいといら結果がえられた ものと考えられる。

3） スラリーの粘度

重油にくらべ，石炭を含む重油スラリーの粘度は非 常に高くなることが予想され，乙たがつてスラリーの 粘度は, ポンプの能力, 輸送管長, 管径をきめる上で 重要なポイントとなる。

石炭一重油スラリーは, 一般に非ニュートン流体(ビ ンガム流体）の性状を示すため, 濃度と温度との間に はまだ定量的な関係が求めておらず，一，二の実験式

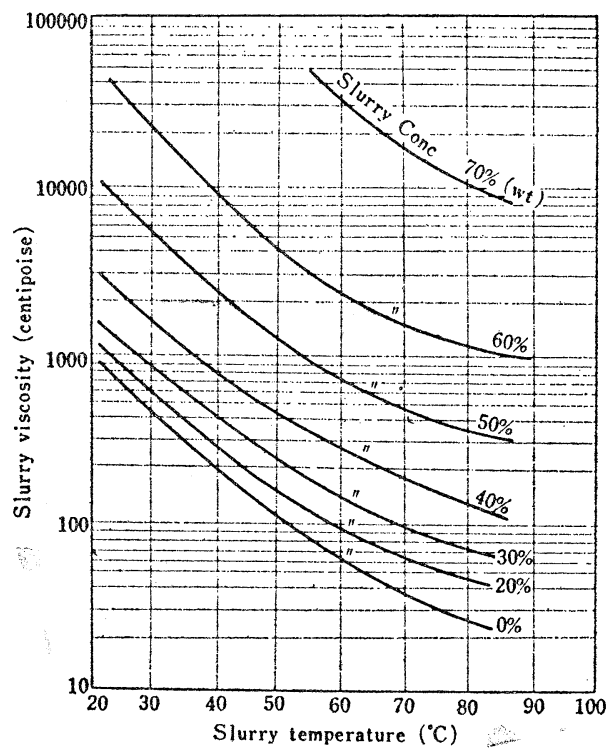

Fig. 2 Slurry viscosity 
を用いて見掛け粘度を求め，大体の見当をつけている のが現状である。

そこでわれわれは，回転式粘度計を用いて各濃度の

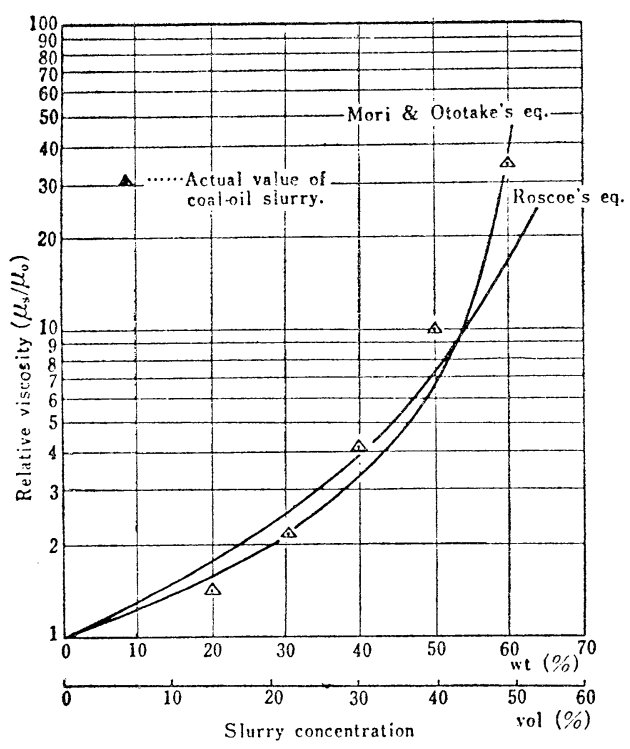

Fig. 3 Relation between slurry concentration and relative viscosity

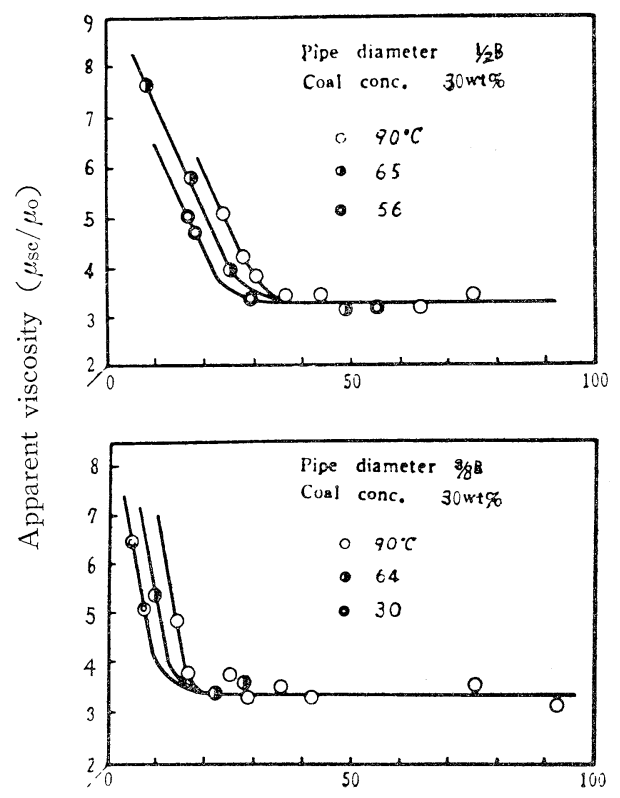

スラリーについて温度と粘度との関係を求めた。結果 はFig. 2 に示すようである。

また Fig. 3 は，Fig. 2 のデータ在重油に対する粘 度比 (相対粘度)にな却してプロットしたもので，こ の図からわかるようにスラリー濃度が 50\% (wt) の

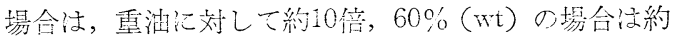
60倍となり，50〜60\% 灌度のところでスラリ一粘度 は急激に上杽しており，この湦度の前後がスラリーと して奏際に取扱いうる限界と判断される。

なお，Fig. 3 に示した関係は，従来報告されている 实験式のうち， Roscoe ${ }^{2)}$ および森，乙竹の式 ${ }^{3)}$ が比 較的よく一致する。これらの実験式はそれぞれつぎの ようである。

Roscoe $: \mu_{s} / \mu_{0}=\left(1-1.35 x_{n}\right)^{-2.5}$

森, 乙竹: $\mu_{s} / \mu_{0}=\left[3\left(\frac{1}{x_{n}}-\frac{1}{0.52}\right)\right]+1 \cdots$

但し $\mu_{s} / \mu_{0}$ : それぞれスラリー，重油の粘度 $x_{n}$ : スラリー中の石炭濃度 ( $\left.\mathrm{Vol}, \%\right)$

4) 輸送管内における限界流速

スラリーの管内流速が十分速い場合は，石炭粒子は 均一に分散して輸送されるが，これよりも流速が遅く なると管内垂直断面の下の方ほど濃度が高くなり，粗
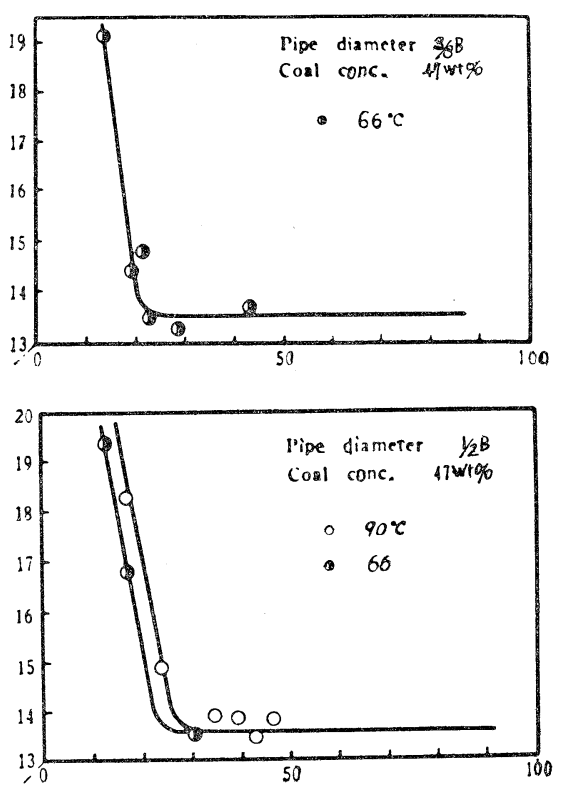

$\mu_{\mathrm{sc}}$ : Apparent viscosity of slurry

$\mu_{0}$ : Viscosity of feul oil at the same temperature

Fig. 4 Relation between apparent viscosity and velosity of slurry in the pipe 
粒子は管底で懸濁状態を保ちながら跳転してはこばれ る。したがつて，この時はまだ粒子は沈積していない が, さらに遅くなると, 粒子の沈積が始まり管の流れ に対する有效断面積は減少し輸送抵抗が増大し, これ にともない流速が急速に小さくなり, 管内閉塞が生じ る。

したがつて, スラリ一輸送ではこの限界流速を求 め，これにもとづき経済的な流速学選ぶことが大切で ある。

Fig. 4 は, 前述の実験用輸送装置によつてスラリー 輸送時の管内圧損失を測定しこの結果から,均一流体 の層流の場合の圧損失計算に広く用いられる Fanning の式から，スラリーの見掛け粘度を逆算し，これを重 油粘度との比で表わし流速に対してプロットしたもの である。Fanning の式は次式によつて示される。

$$
\begin{aligned}
\Delta P=32 L . \mu \cdot u / g \cdot D^{2} & \\
\text { 但し } \Delta P & ; \text { 圧損失 } \quad\left(\mathrm{kg} / \mathrm{m}^{2}\right) \\
L & ; \text { 管の長さ }(\mathrm{m}) \\
\mu & ; \text { 流体の粘度 }(\mathrm{kg} / \mathrm{m} \mathrm{sec}) \\
u & ; \text { 流速 } \quad(\mathrm{m} / \mathrm{sec}) \\
g & ; \text { 重力加速度 }\left(\mathrm{m} / \mathrm{sec}^{2}\right) \\
D & ; \text { 管径 } \quad(\mathrm{m})
\end{aligned}
$$

Fig. 4 から明らかのように, 粘度 $\left(\mu_{s} / \mu_{0}\right)$ 比が急 激に上昇する時の流速が粒子の沈積し㕸める限界流速 でこの結果からつぎのことがいえる。

（1）管径によつて変わり，管径が大きくなれば増 大する。
(2) $30 \sim 50 \%(w t)$ の石炭濃度の範囲内では, 濃 度による影響は小さい。

（3） スラリー温度によつて变化するが，その程度 はあまり大きくない。

\section{III. スラリー吹込み設備}

以上の石炭およびスラリーの性状々ついての基礎研 究にもとづき，炉内容積 $1,042 \mathrm{~m}^{3}$ の当室蘭製鉄所第 1 高炉にスラリー吹込夕設備を設置した。

Fig. 5 に乾燥炭を使用する場合の設備のフロシー トを示す。

微粉炭堅型乾燥機で乾燥後ローヘツド型の振動篩 によつて規定の粒度に篩分けられ, 節下の多空気輸送 され, ホッパーに貯蔵される。この微粉炭は, 定比率 自動供給機によつて重油と同時に所定量 No. 1 混合 器に供給され，攪橶混合されてスラリ一状になる。

湿炭の場合には, 貯炭場よりコンベアで直接ホッパ 一に貯蔵され，ついで乾燥炭の場合と同様 No. 1 混 合器に定量的に切り出される。また事前に篩分けを行 ならことができないので，粗粒炭が多数スラリー中に 混入し，バーナ一閉塞の原因となることを防ぐため， スラリー状としたあとにミル工程をとおす。

所定の濃度に調整されたスラリーは，ストレーナ一 で大きな異物を除去したのち，ポンプにより加熱器を 経て高炉炉前まで圧送される。

加熱器で $100^{\circ} \mathrm{C}$ に加熱され㶱前まで压送されたスラ リーは，分岐して各羽口直管部に雨入されている䫟射 バーナーから炉内に吹込まれる。

石炭一重油スラリーの吹込多将，コスト低減と品質

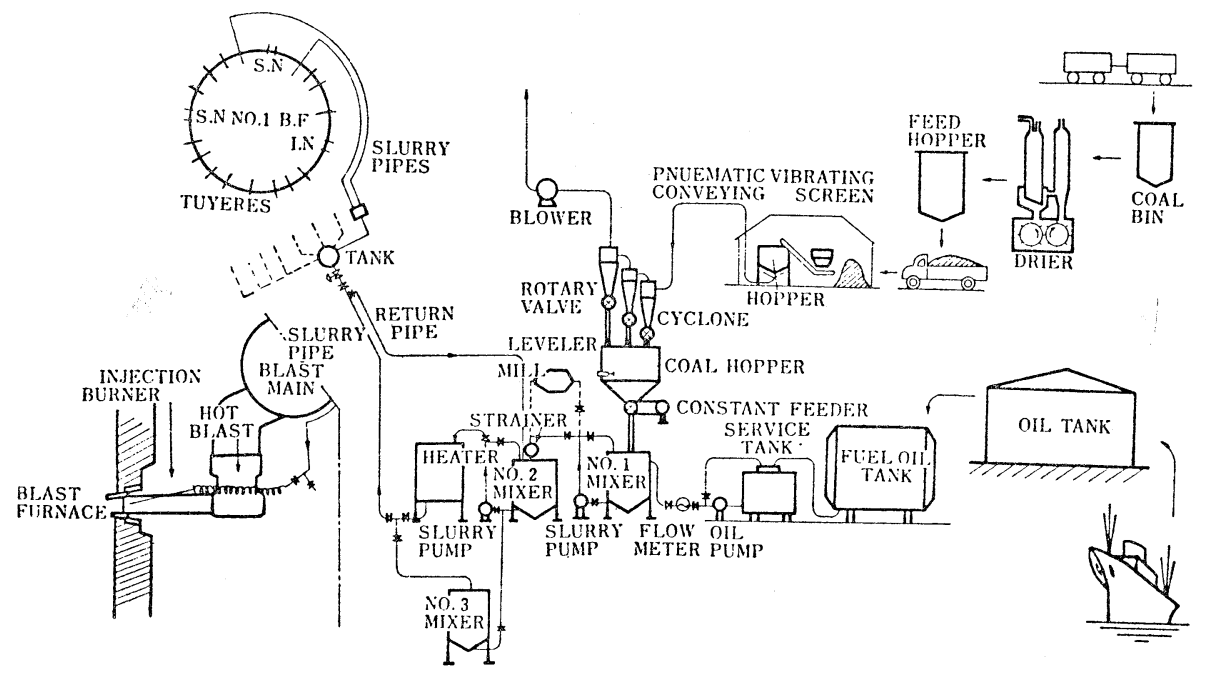

Fig. 5 Slurry injection system (Fuji, Muroran) 


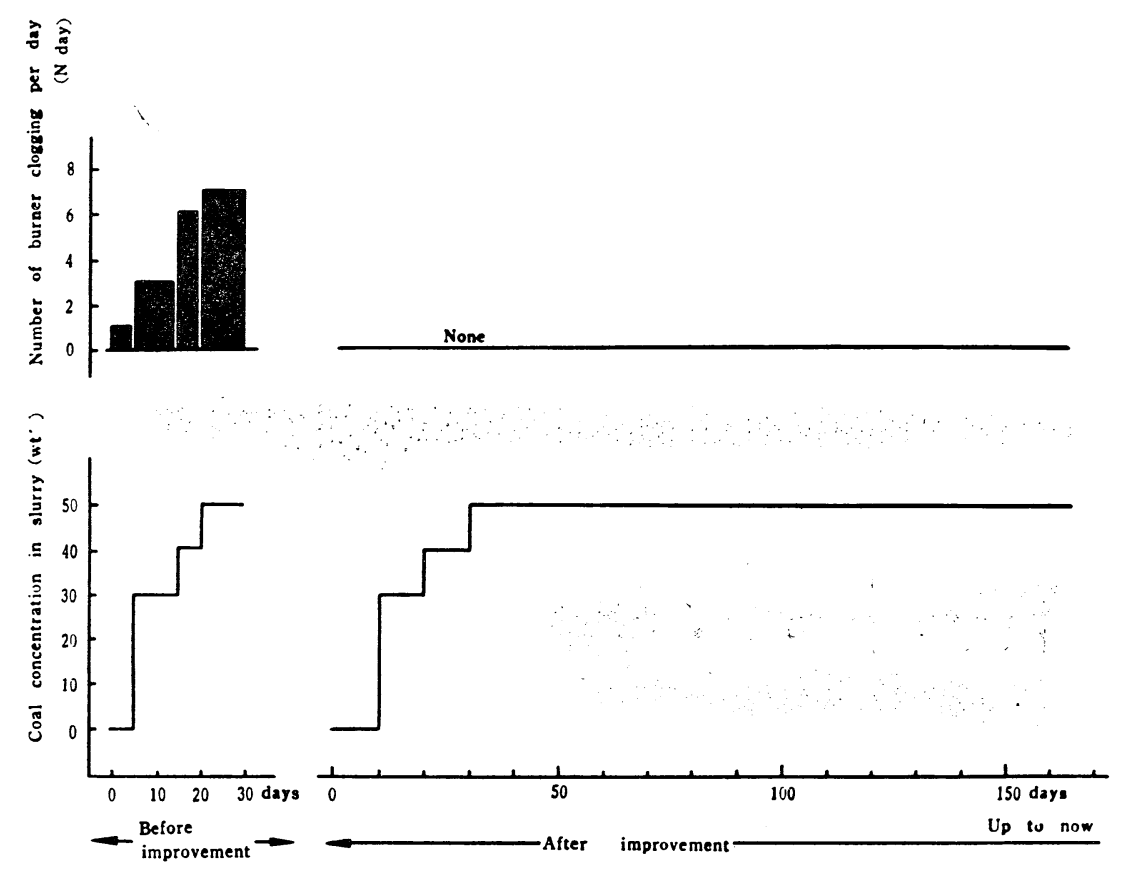

Fig. 6 Elimination of burner clogging by improvement of injection method

向上の両面に大きなメリットがあるが，このメリット は石炭濃度が高いほど増すことになる。

しかしながら，石炭濃度が $50 \%$ (wt) 程度に高くな つた場合，バーナ一開塞が若干生じた。この原因とし ては，炉前の本管とこれから各羽口に行く枝管との分 岐方法にあると考えられた。すなわち, 各羽口への分 岐は, 設備コスト低減の趣旨から, 先にも述べたよう に高炉の炉まわりにめぐらした 1 本の輸送本管から順 次各羽口に分岐させただけといら簡単なものであつ た。このため各羽口から均等に吹込むことが中々むゔ かしく, 特に石炭濃度が高くなりスラリーの粘度が高 くなると，これに応じて輸送時の管内圧損失も大きく なつて堌々吹达み量にかたよりが生じるようになつ た。その結果流量の少なくなつた箇所で石炭粒子が沈 積しがちとなり，これが主因となつてバーナ一閉塞を おこしたものと考えられた。

また, 各羽口ごとのスラリ一吹込み量の不均等は,
高炉操業上炉況の不調をま衩き，また送風支管（羽口 直管部）への燃料の逆流などのトラブルをひき起す。 そこで, 各羽口からの吹込み量を均等化できるよう 計装化を行なつた。この結果は Fig. 6 に示すよう に, $50 \%$ (wt) スラリーでもバーナー閉塞は全くなく なり，炉況もきわめて順調になつた。

噴射バーナーのノズル径は, 噴射固形物の直径の 3 倍程度のものが必要であるといわれているが, われわ れは閉塞をふせぐため，炉況に悪影響をおよぼさない かぎりノズル径を大きくするという方針をとり，現在 $5 \mathrm{~mm} \phi$ のものを使用している。

以上のほか付帯設備としては，スラリーの吹込み量 が，設定された所定量に保持され，また，バーナ一閉 塞が起らないための工夫として, 自動蒸気パージ装置 が設置されている。自動的にパージが行なわれるのは つぎの場合である。

(1) 停電時

Table 2 Properties of fuel oil

\begin{tabular}{|c|c|c|c|c|c|c|c|c|}
\hline \multicolumn{3}{|c|}{ Chemical analysis } & \multirow{2}{*}{$\begin{array}{c}\text { Density } \\
15^{\circ} \mathrm{C} / 4^{\circ} \mathrm{C}\end{array}$} & \multirow{2}{*}{$\begin{array}{l}\text { Inflam- } \\
\text { mable } \\
\text { temp. }{ }^{\circ} \mathrm{C}\end{array}$} & \multirow{2}{*}{$\begin{array}{c}\text { Viscosity } \\
\text { CS } \\
\left(50^{\circ} \mathrm{C}\right)\end{array}$} & \multirow{2}{*}{$\begin{array}{l}\text { Fluid } \\
\text { point } \\
{ }^{\circ} \mathrm{C}\end{array}$} & \multirow{2}{*}{$\begin{array}{c}\text { Residue } \\
\text { carbon } \\
\%\end{array}$} & \multirow{2}{*}{$\begin{array}{c}\text { Heat value } \\
\mathrm{kcal} / \mathrm{kg}\end{array}$} \\
\hline $\mathrm{C} \%$ & $\mathrm{H} \%$ & $\mathrm{~S} \%$ & & & & & & \\
\hline 84.9 & 11.8 & 2.5 & 0.940 & 120 & 140 & -7.5 & 7.6 & 10,500 \\
\hline
\end{tabular}




\section{Table 3 Properties of coal}

\begin{tabular}{|c|c|c|c|c|c|c|c|c|}
\hline \multirow{2}{*}{$\begin{array}{l}\mathrm{H}_{2} \mathrm{O} \\
\%\end{array}$} & \multirow{2}{*}{$\begin{array}{c}\text { V.M. } \\
\%\end{array}$} & \multirow{2}{*}{$\begin{array}{c}\text { Ash } \\
\%\end{array}$} & \multirow{2}{*}{$\begin{array}{c}\text { Heat value } \\
\mathrm{kcal} / \mathrm{kg}\end{array}$} & \multirow{2}{*}{ C.B.I. } & \multicolumn{4}{|c|}{ Chemical analysis } \\
\hline & & & & & $\mathrm{C} \%$ & $\mathrm{H} \%$ & $\mathrm{~N} \%$ & $\mathrm{~S} \%$ \\
\hline 3.60 & 39.28 & 10.74 & 7,220 & $1^{1 / 2}$ & 72.26 & 6.00 & 0.23 & 0.34 \\
\hline
\end{tabular}

Table 4 Comparison of Injecting Conditions

\begin{tabular}{|c|c|c|c|c|c|c|c|c|c|c|c|}
\hline & & \multirow[b]{2}{*}{$\begin{array}{c}\text { Fuel oil } \\
\text { temp. }\end{array}$} & \multirow[b]{2}{*}{$\begin{array}{l}\text { Fuel oil } \\
\text { rate }\end{array}$} & \multirow[b]{2}{*}{ Coal rate } & \multirow[b]{2}{*}{ Fuel rate } & \multirow{3}{*}{$\begin{array}{c}\text { Temp.at } \\
\text { No. } 2 \\
\text { mixer } \\
{ }^{\circ} \mathrm{C}\end{array}$} & \multirow{3}{*}{$\begin{array}{l}\text { Temp. of } \\
\text { injecting } \\
\text { fuel } \\
{ }^{\circ} \mathrm{C}\end{array}$} & \multirow{3}{*}{$\begin{array}{l}\text { Injecting } \\
\text { pressure } \\
\left(\mathrm{kg} / \mathrm{cm}^{2}\right)\end{array}$} & \multicolumn{3}{|c|}{ Velocity in pipes $(\mathrm{m} / \mathrm{sec})$} \\
\hline & & & & & & & & & & & Burne \\
\hline & & ${ }^{\circ} \mathrm{C}$ & $1 / \mathrm{h}$ & $\mathrm{kg} / \mathrm{h}$ & $1 / \mathrm{h}$ & & & & $\left(1^{1} / 4^{2} \mathrm{~B}\right)$ & $(1 / 2 \mathrm{~B})$ & \\
\hline \multirow{2}{*}{ Fuel oil } & $\int$ No. 1 & 70 & 3,200 & 0 & 3,200 & 66 & 95 & 1.0 & 0.89 & 0.44 & 12.7 \\
\hline & No.2 & 70 & 2,900 & 0 & 2,900 & 65 & 95 & 1.2 & 0.81 & 0.40 & 11.5 \\
\hline \multirow{2}{*}{$\begin{array}{l}30 \text { wt \% } \\
\text { slurry }\end{array}$} & (No.1 & 55 & 2,300 & 900 & 2,900 & 55 & 90 & 1.4 & 0. & 0. & 4.0 \\
\hline & No.2 & 75 & 2,200 & 870 & 2,800 & 70 & 95 & 1.4 & 0.78 & 0.38 & 3.9 \\
\hline \multirow{2}{*}{$\begin{array}{l}50 \text { wt \% } \\
\text { slurry }\end{array}$} & No. 1 & 75 & 1,650 & 1,500 & 2,650 & 70 & 90 & 1.7 & 0.73 & 0.36 & 3.7 \\
\hline & $\{$ No.2 & 75 & 1,500 & 1,350 & 2,400 & 70 & 90 & 1.5 & 0.67 & 0.33 & 3.3 \\
\hline
\end{tabular}

Burner diameter: $3 \mathrm{~mm} \phi$ for fuel oil

$5 \mathrm{~mm} \phi$ for slurry

(2) バーナーが閉塞しかけたとき
(3) 圧送圧力の低下時
(4) 送風圧力低下時
(5) 操作用空気圧力低下時

Table 2，3 に現在使用している重油, 石炭の性状
を示す。また Table 4 はスラリ一吹込み時の操業条 件を重油の場合と対比して示したものである。

\section{IV スラリー吹込みによる高炉操業効果}

Table 5 にスラリー吹込夕時の高炉操業成績を重油 の場合と比較して示す。スラリーおよび重油それぞれ

Table 5 Results of the fuel injection test at Muroran No. 1 B.

\begin{tabular}{|c|c|c|c|c|}
\hline & \multirow[b]{2}{*}{$\begin{array}{l}\text { Fuel oil } \\
\text { Aug., } 1964 \\
10 \text { days }\end{array}$} & \multicolumn{3}{|c|}{ Fuels and Injecting period } \\
\hline & & $\begin{array}{l}30 \text { wt } \% \\
\text { slurry } \\
\text { Sept., } 1964 \\
10 \text { days }\end{array}$ & $\begin{array}{l}\text { Fuel oil } \\
\text { May, } 1965 \\
10 \text { days }\end{array}$ & $\begin{array}{c}50 \text { wt } \% \\
\text { slurry } \\
\text { Apr., } 1965 \\
10 \text { days }\end{array}$ \\
\hline Fuel oil ratio $\cdots \cdots \cdots \cdots \cdot \mathrm{kg} / \mathrm{t}$-pig & 48 & 0 & 53 & 0 \\
\hline Slurry ratio $\cdots \cdots \cdots \cdots \cdots \cdots \cdot \mathrm{kg} / \mathrm{t}$-pig & 0 & 48 & 0 & 52 \\
\hline $\mathrm{Wt} \%$ of $\operatorname{coal} \ldots \ldots \ldots \ldots \%$ & 0 & 23 & 0 & 48 \\
\hline Iron production $\cdots \cdots \cdots \cdot \mathrm{t} / \mathrm{\theta}$ & 1,282 & 1,351 & 1,246 & 1,236 \\
\hline Coke ratio $\cdots \cdots \cdots \cdots \cdots \cdots \cdot \mathrm{kg} / \mathrm{t}$-pig & 459 & $456^{a}$ & 459 & 468 a \\
\hline Blast volume $\cdots \cdots \cdots \cdots \cdot \mathrm{m}^{3} / \mathrm{min}$ & 1,220 & 1,330 & 1,264 & 1,182 \\
\hline Blast temperature $\cdots \cdot . \cdot{ }^{\circ} \mathrm{C}$ & 930 & 950 & 942 & 938 \\
\hline Moisture in blast $\cdots \cdots \cdot \mathrm{g} / \mathrm{Nm}^{3}$ & 18.3 & 11.9 & 6.8 & 8.2 \\
\hline Slag ratio $\cdots \cdots \cdots \cdots \cdots \cdots \cdot \mathrm{kg} / \mathrm{t}$-pig & 296 & 268 & 255 & 303 \\
\hline Slag basicity $\cdots \cdots \cdots \cdots \cdot \mathrm{CaO} / \mathrm{SiO}_{2}$ & 1.26 & 1.33 & 1.34 & 1.34 \\
\hline Si in pig iron $\ldots \ldots \ldots \%$ & 0.66 & 0.63 & 0.73 & 0.96 \\
\hline $\mathrm{S}$ in pig iron $\cdots \ldots \ldots \ldots \%$ & 0.024 & 0.019 & 0.036 & 0.023 \\
\hline Top gas temp. $\cdots \cdots \cdots \cdot{ }^{\circ} \mathrm{C}$ & 153 & 146 & 183 & 162 \\
\hline $\mathrm{H}_{2}$ in top gas $\cdots \cdots \cdots \cdots$ & 3.3 & 3.1 & 2.9 & 2.7 \\
\hline $\mathrm{CO} / \mathrm{CO}_{2}$ in top gas $\cdots$ & 1.30 & 1.28 & 1.25 & 1. 17 \\
\hline
\end{tabular}

a : Corrected coke ratio taking the coke ratio of fuel oil period as a base condition. 
の吹込み期間は装入物その他の高炉操業条件をできる だけ同じにするようつとめた。

Table 5 から明らかなよらに, 石炭濃度 30\% (wt) スラリーの吹达多期間は出銑量, コークス比共重油単 味の場合と大差は認められなかつたが, 石炭濃度 50\% (wt) スラリー吹込及期間は重油単味の期間よりもか えつてコークス比が高くなつている。しかし，これ はこの期間の炉況が不安定で棚吊り気味であつたこと と，またそのために吹込みを断続せざるを得なかつた などのためと考えられ，概括的にはスラリ一吹込み時 の操業成續は, 重油吹込み時のそれと大差ないものと 判断された。

ただ一般的な傾向として, 同一操業条件下で重油単 味からスラリーに切替えると, 炉況が熱目に向らのが 認められることから, 前述のように, スラリ一吹込み は重油吹込みよりも熱風温度上昇, あるいは熱風添加 湿分低減などによる熱補償が少なくて済み，このこと はその分だけ重油より多量に吹込めることを裏付ける ものと考えられた。現に, その後のスラリ一吹込み操 業では重油吹込みの場合よりも銑鉄トン当り $10 \mathrm{~kg}$ 増 の吹込みを行なつている。

また銑鉄成分についてみると，スラリ一吹込み期間 の銑鉄の $\mathrm{S}$ 含有量は重油吹込み期間のそれに比べて,
かなり低下していることがわかる。最近，鋼材品質の 改良のため銑鉄の $\mathrm{S}$ 含有量を極力低下するよう強く要 請されているので，これは大きなメリットである。

$$
\mathrm{V} \text {. 結言 }
$$

当室蘭製鉄所では，1961年夏，石炭一重油スラリー を高炉に吹込むための研究に着手し，1963年，第 1 高 炉に吹込み設備設置し, 現在出銑口の雨側を除く羽 口16本より石炭濃度 50\% (wt) のスラリーを重油単味 の場合より約 $10 \mathrm{~kg} / \mathrm{t}-\mathrm{Pig}$ 多く吹込んでいる。

このスラリ一吹込みによつて, 銑鉄中のイオウ含有 量が低下し, 品質が改良され, 最近の鋼材市場のきび しい品質面の要請に応ずるに大きく貢献した。

きた, 出銑量などの高炉操業成績への効果も重油吹 込みの場合とほぼ等しく, 重油よりも安価のため銑鉄 コストが低減した。

と同時に，このスラリ一吹込み技術は，重油との競 合のため使用範囲の拡大が望まれている石炭の新規需 要を開拓するものとして, 国内資源活用の見地から注 目されるべき技術であるといえよう。

\section{文 献}

1) U. S. A. Patent, 3, 168, $350(1965,2)$

2) R. Roscoe, Erit. J. Appl. Phys. 3, 264 (1952)

3) 森, 乙竹, 化学工学, 20, 488 (1956)

\title{
Coal Slurry Injection into Blast Furnace
}

\author{
by Kōzō Morinaga, Kikuo Tajima, \\ Yoshiteru Jōmoto, Yūzō Kanayama \\ and Hiroshi Matsuoka
}

(Fuji Iron and Steel Co., Ltd)

\begin{abstract}
SYNOPSIS:-One of the methods for reducing blast furnace iron-making cost is to inject auxiliary fuels throngh the tuyeres.

As for the fuel used, heavy oil is commonly used with one exception or two.

In using heavy oil as auxiliary fuel, however, there arises the problem of an increase in sulfur content in the pig iron, and of heat compensation to increase the fuel used.

These problems can be solved by using coal produced in Hokkaidō, where the Muroran Works of Fuji Iron and Steel Co., Ltd. is located.

On the other hand, however, since coal price fluctuation in Japan is wide, it would be far more advantageous, in reducing cost, to set up a technique for injecting a slurry-form fuel, a mixture of coal and heavy oil.
\end{abstract}


In the summer of 1961, research on studying the selection of coals, viscosity of slurry and critical velocity in piping was launched to ascertain the properties of slurry.

On the basis of the knowledge gained, slurry equipment was provided for the No. 1 blast furnace at the Muroran Works, with an inner volume of $1,042 \mathrm{~m}^{3}$, (afterwards relined to $1,126 \mathrm{~m}^{3}$ ) and actual slurry injection test was carried on, and now slurry of $50 \mathrm{wt} \%$ coal concentration is being injected quite satisfactory into blast furnace through 16 tuyeres.

By means of slurry injection, the sulphur content of pig iron thus produced has been reduced. The effect of using slurry on the out-put of pig iron and other blast furnace performance is about the same as in the case of using heavy oil alone. But, since slurry is cheaper than heavy oil, the use of slurry has cut down the cost of pig iron production.

\section{7年燃料おっび燃焼に関する講習会 テキスト領布について}

先般 4 月行ないました上記講習会のテキストの残部が少々ありますので, 御希望の方には実費にてお領ち致します。

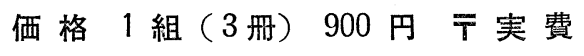

社団法人 燃 料 協 会 